\title{
5. Sınıf Türkçe Ders Kitabında Saygı İfade Kalıpları
}

\section{Respect Expression Patterns in 5th Grade Turkish Textbook}

Filiz METE, Sorumlu Yazar, Doç. Dr.

Hacettepe Üniversitesi, Eğitim Fakültesi.

E-mail: flzmt27@gmail.com

ORCID: 0000-0002-8835-3884

Murat DAĞ, Dr. Öğrenci, MEB Öğretmen.

E-mail: dag390@gmail.com

ORCID: 0000-0001-6152-2425

ISSN: 1303-880X

e-ISSN: 2667-7504

http://ded.dem.org.tr

Geliş/Received: 15.07.2019

Kabul/Accepted: 22.10.2019

Makale Yayın: 25.12.2019

Makale Türü/Article Type:

Araştırma/Research
Atıf/Citation:Mete, F. \& Dağ, M. (2019). 5. Sınıf Türkçe ders kitabında saygı ifade kalıpları. Değerler Eğitimi Dergisi,17 (38), 333-355. DOI: 10.34234/ ded.592008 
Öz: Okula başlayana kadar tamamen doğal yollarla ailesinden değerler eğitimi alan çocuğa, okula başladığı zaman bu değerlerin öğretimi planlı ve bilinçli şekilde gerçekleştirilmektedir. Zira değerler dolaylı olarak, toplumların yaşam ve gelişim seyrini değiştirebilme gücüne sahiptir. Toplumsal değerlerin ve ahlaki standartların gelecek kuşaklara aktarılması önemlidir. Bu araştırmanın amacı; Türkçe dersi kapsamında değerler eğitiminde karşılık bulan saygı ifade kalıplarının 5. sınıf Türkçe ders kitabında yer alma durumunu tespit etmek ve mevcut durumu ortaya koymaktır. Araştırmanın problem durumu, değerler eğitimiyle ilgili saygı ifade kalıplarının 5. sınıf Türkçe ders kitabında yer alma düzeyinin yeterli olup olmadığıdır. Bu bağlamda metinlerde ve etkinliklerde geçen saygı ifade kalıplarının neler olduğu, karşılık ifadelerinin olup olmadığı ve doğrudan saygı ifade kalıplarının ele alındığı tema, metin veya etkinliğin olup olmadığ araştırılmıştır. Çalışma, nitel araştırma olarak desenlenmiş ve nitel araştırma yöntemleri kapsamında, doküman taraması kullanılmıştır. Bu araştırmada Özgün Yayınevi'nin 5. sınıf Türkçe ders kitabıdır. Bu bağlamda kitapta yer alan metinlerin tamamı ve metne bağlı etkinliklerin hepsi incelemeye dâhil edilmiştir. Elde edilen verilerin analizinde, betimsel analiz yöntemi kullanılmıştır. Belirlenen ifade kalıpları tablolar hâlinde sunulmuş ve bulgular yorumlanarak mevcut durum ortaya koyulmuştur. Sonuçta 5. sınıf Türkçe ders kitabının saygı değerini içerdiği ancak saygı ifade kalıplarına yer verme konusunda metin veya etkinliklerde yeterli olmadığı belirlenmiştir.

Anahtar Kelimeler: Türkçe öğretimi, Değerler eğitimi, Sayg1, İfade kalıpları

$\&$

Abstract: Children who receive values education from their parents in a completely natural way until they start school, where they will be taught values in a planned and conscious way. Because values indirectly have the power to change the life and development of societies. It is important to transfer social values and moral standards to future generations. The aim of this research is to determine the status of expressions of respect in the 5th grade Turkish textbook. The research problem revolving around whether or not the level of respect for values education is sufficient in the 5th grade Turkish textbook. In this context, the expressions of respect in the texts and activities and whether there are reciprocal expressions and whether there is a theme, text or activity that contains direct expressions of respect are investigated. The study was designed as qualitative research and document analysis was used within the scope of qualitative research methods. The tool used in this research is the 5 th grade Turkish text- 
book. In this context, all the texts in the book and all the activities related to the text were included in the analysis. Descriptive analysis method was used in the analysis of the obtained data. The statements were presented in tables and the findings were interpreted and the current situation was revealed. As a result, it was determined that the textbook contains the value of respect, yet in terms of the expressions of the respect value in texts or activities, it was found to be insufficient.

Keywords: Turkish teaching, Values education, Respect, Expression patterns

\section{Giriş}

Doğruyu yanlıştan, eğriyi doğrudan ayırabilmek, saygılı davranmak insanı hayvandan ayıran özelliktir, erdemdir. İdeal insan içinde yer aldığ 1 toplumun değerlerine, ahlaki norm ve kurallarına uygun yaşar. Toplumu bir arada tutan kültür dokusunu ise ortak değerlerin ilmekleri oluşturur. İçten bir güç olarak değerler; bireysel davranışları etkiler; yaşamda ikilemde kalma durumunda karar vermeyi kolaylaştırır; toplum ya da bireyler tarafından benimsenen birleştirici olgulardır; bireysel algı ve gerçeğin yorumlanmasını etkiler; davranışları kontrol etmeyi sağlar; kişi ve toplumların istek ve amaçlarını temsil eder; zaman içerisinde çeşitli etmen ve bireylere göre değişebilir; duygu yüklüdür, düşünce ve anlayışa güç verir, davranışları yönlendirir; insan kişiliğinin etik, sosyo-ekonomik, zihinsel, politik, fiziksel, estetik, dinsel gibi çeşitli boyutlarını içerir (Kasapoğlu, 2013, Aktaran: Güçlü, 2015: 720). Değerler, kökleri geleneklerimiz ve dünümüz içinde, gövdesi ve dalları bu köklerden beslenerek bugünümüze ve yarınlarımıza uzanmaktadır (Millî Eğitim Bakanlığı, 2019: 4).

Değerleri öğretme görevi öncelikle ailelerin, sonrasında ise öğretmenlerin sorumluluğundadır. Çocuk değer eğitimini ilk olarak aileden alır ama değerlerin sistemli olarak öğretimi okullarda gerçekleştirilir (Sallabaş, 2012: 60). Çünkü bireylerin sahip olduğu değerler dolaylı olarak, toplumların yaşam ve gelişim seyrini değiştirebilme gücüne sahiptir. Bu yüzden toplumsal değerlerin ve ahlaki standartların gelecek kuşaklara aktarılması önem arz etmektedir. Bundan dolayı, değerler eğitimi konusu 2005 yılında hazırlanan öğretim programlarında yerini almıştır. Özellikle bu tarihten sonra değerler eğitimi vermenin yansımalar1 ve etkililiği konusunda araştırmalar gerçekleştirilmiştir. Örneğin, Keskinoğlu (2008), ilköğretim 5. sınıf öğrencileriyle yaptığı bir araştırma sonucunda değerler eğitimi alan öğrencilerin bu eğitimi almayanlara göre ahlaki olgunluk düzeyinin daha fazla geliştiği ve saldırganlık eğilimlerinin azaldığı tespitinde bulunmuştur. Bu sonuç değerler eğitimi verilmesi gerekliliğini vurgular niteliktedir. 
Öğretim programlarında da yer aldığı gibi değerlerin öğretimi toplumun geleceği için önem arz etmektedir. Birey davranışlarının temeli, kişiliği oluşturan değerlerin nitelikleriyle bağlantılıdır. Temel insani özelliklerimizi oluşturan değerlerimiz, hayatımızın rutin akışında ve karşılaştığımız sorunlarla başa çıkmada eyleme geçmemizi sağlayan kudretin ve gücün kaynağıdır (MEB, 2019: 4). $\mathrm{Bu}$ bağlamda eğitim; teorik bilgiyi verdiği bilişsel alandan olduğu kadar değerlerin öğretimiyle duyuşsal ve bu değerler bireyin davranışlarını etkilediği için de davranışsal boyuttan sorumlu tutulur. İşcan (2007) ilköğretim öğrencilerinin değerlerle ilgili bilişsel davranışları, duyuşsal özellikleri ve değerleri gösterme düzeylerini tespit çalışmasında öğrencilerin toplumsal değerleri sadece tanıma ve ayırt etme düzeyinde olduklarını bulgulamıştır. Benzer şekilde Coşkun (2011) da 5. sınıf öğrencileriyle yaptığı çalışmada öğrencilerin bazı değerlerin gerektirdiklerini çoğu zaman bildiklerini ancak uygulamaya geçiremediklerini belirlemiştir.

"Eğitim programı"; öğretim programları, öğrenme öğretme ortamları, eğitim araç gereçleri, ders dış1 etkinlikler, mevzuat gibi eğitim sisteminin tüm unsurları göz önünde bulundurularak oluşturulur (MEB, 2019: 4). Bu anlayışla oluşturulan öğretim programlarında değerlerimiz, ayrı bir program veya öğrenme alanı, olarak yer almamış aksine bütün eğitim sürecinin nihai gayesi ve ruhu olarak kabul edilip, öğretim programlarının her birine ve birimine yansıtılmıştır. 2019 Türkçe öğretim programında geçen "kök değerler" şunlardır: adalet, dostluk, dürüstlük, öz denetim, sabır, saygı, sevgi, sorumluluk, vatanseverlik, yardımseverlik.

Türk (2009) yaptığı yüksek lisans çalışmasında 2005 ders programlarını incelemiş ve değerler eğitimi kapsamında yer alan değerleri şöyle listelemiştir: Adil olma, Bağımsızlık, Barış, Bilimsellik, Çalışkanlık, Dayanışma, Duyarlılık, Eşitlik, Hoşgörü, Özgürlük, Sayg1, Sevgi, Misafirperverlik, Sorumluluk, Temizlik, Dürüstlük, Vatanseverlik, Sağlıklı olmaya önem verme, Yardımseverlik, Aile birliğine önem verme (s.12). Listelenen değerler incelendiğinde sayg1 değerinin aslında neredeyse bütün değerlerin temelini oluşturduğu anlaşılacaktır. Sayg1nın olmadığı durumlarda; sevgi, adalet, barış, hoşgörü veya yardımseverlikten gibi pek çok değerden bahsetmek mümkün değildir. Bu durum gözetilerek çalışma sadece saygı değeri ile sınırlandırılmıştır.

Literatürde değerler eğitimiyle yapılan çalışmalar genellikle sosyal bilgiler, hayat bilgisi veya tarih alanlarıyla bağlantılı ele alınmıştır veya öğretimde kullanılan materyallerin incelenmesi yoluyla gerçekleştirilmiş̧ir. Söz konusu alan- 
larda pek çok araştırmacı ders sürecinde kullanılan ders kitapları, edebi eserler, hikâyeler, metinler, gazeteler, dergiler gibi materyalleri değerler eğitimi açısından içerik ve kullanım etkileri boyutunda incelemiştir (Aslan, 2009; Kumbasar, 2011; Atmaca, 2011; Kaynak, 2012; Demirtaş, 2012; Aktürk, 2012; Y1lmaz, 2012; Latifoğlu, 2013; Biçer, 2013; Akkaya, 2013; Bağc1, 2013; Kantar, 2014; Kova, 2014; Ercan, 2014; Selek, 2014; vb.) veya programların incelenmesi ve etkisi üzerine araştırmalar gerçekleştirilmiştir (Aydın, 2006; Tokdemir, 2007; Yazar, 2010; Izgar, 2013; Uzunkol, 2014; Engin, 2014; vb.). Değerler eğitiminde yaklaşım ve kullanılan yöntemlerle ilgili çalışmalar da (Can, 2008; Çengelci, 2010; Baysal, 2013; Akgül, 2014; vb.) mevcuttur. Ancak doğrudan Türkçeyle ilişkili veya Türkçe ders kitaplarıyla bağlantılı değerler eğitimi konusunda yapılan (Şen, 2008; Padem ve Aktan, 2014; Pilav ve Erdoğan, 2016; Gül, 2017; Deniz, Karagöl, 2018) çalışmaların az/yetersiz sayıda olduğu görülmüştür. Söz konusu çalışmaların ortak özelliği ise kitap ve kaynaklarda yer alan değerlerin belirlenmesi ve kullanım sıklığı araştırması olmasıdır. Sonuçları incelendiğinde ise hemen hemen her çalışmada sevgi değerinin en sık kullanılan kavram olduğu yönünde bulgular mevcuttur. Benzer şekilde Şen (2008) de altıncı sınıf için hazırlanan 5 adet Türkçe ders kitabındaki metinlerin ilettiği değerleri incelemiş, değerlerin metinlerdeki dağılımlarını listelemiş ve en çok kullanılan değerin 5 kitapta da sevgi olduğunu ancak metinlerin belirlenen değerlerin aktarımında yetersiz olduğunu tespit etmiş̧ir.

İletişim kurmak için en önemli araç dildir. Saygılı olmanın somut göstergelerinden birisi iletişim kurarken saygı ifadelerini kullanmaktır. Türkçe dersleri, dil becerilerini geliştirmek üzere tasarlanmıştır ve sözlü veya yazılı ifadelerin doğru ve etkili kullanılması bu dersler kapsamında ele alınır. Baysal (2013) değerler eğitimi uygulamalarıyla ilgili öğretmen görüşlerini aldığı araştırma sonucunda; öğretmenlerin değerler eğitimi uygulamalarında en çok örnek olay kullanma yöntemini, en az ise teşekkür mektubu yazdırmayı kullandıklarını belirlemiştir. Oysa belki de "Teşekkür ederim." bütün dillerde en fazla kullanılan kalıptır ve medeniyetin parolası olarak kabul edilecek derecede önemlidir. Tüm dünyanın kabul ettiği, muhatap olduğumuz bireye gösterdiğimiz sayg1nın en önemli göstergesidir. Teşekkür etmek kadar teşekküre cevap vermek de önemlidir. Örneğin, karşıllı olarak ben teşekkür ederim, rica ederim, bir şey değil, önemli değil gibi ifade kalıpları kullanılır. Bu bağlamda saygı öğretiminin başlangıcı olan teşekkür etme amacıyla kullanılacak kalıpların öğretilmesi için firsatlar oluşturulmalı ve öğrencilerin bu ifadeleri kullanmaları sağlanmalıdır. 
Bütün dillerde olduğu gibi Türkçede de en başta; lütfen ve teşekkür sözcükleri bulunmak üzere saygı ifade eden birtakım hareketler ve ifade kalıpları kullanılmaktadır:

• Teşekkür ederim • Rica ederim • Özür dilerim • Önemli değil

- Buyurun, rica ederim • Lütfen, içeri girin • Bir dakika bekleyin lütfen

• İzin verirseniz • Ben teşekkür ederim • Bir şey değil

- Estağfurullah • Beni mahcup ediyorsunuz • Ne demek, rica ederim, vb.

Değerler eğitiminde söz konusu ifade kalıplarının bilinmesi, içselleştirilmesi ve esas olan nokta, yeri geldiğinde kullanması hedeflenir. Değerler eğitiminin etkisini ölçme çalışmalarında özel geliştirilmiş ölçekler kullanılmakla birlikte ölçek olarak daha çok öğretmenlerin öğrenciyle ilgili davranışsal gözlemlere dayanarak karar verdiğini gösteren çalışmalar mevcuttur (Can, 2008; Keskinoğlu, 2008; Yiğittir ve Öcal, 2011; Ateş, 2013; Özdaş, 2013; vb.). Elbette nihai hedef, bilişsel veya duyuşsal değil davranışsal sonuçlardır. Yani birey, bilen ve içselleştiren ise, bildiklerini ve içselleştirdiklerini davranışlarına yansıtarak yeri geldiğinde kullanabilmesi beklenir. Ancak bilimsel yapılandırılmamış gözlemlerin de güvenilirliği konusunda endişeler bulunmaktadır. Bu bağlamda sadece öğretmen görüşlerine dayalı "Değerler eğitiminden sonra gözlemledim, yeterli buldum." söylemlerinin daha bilimsel gerçekleştirilmesi için destek olunması ve detaylı araştırılması yerinde olacaktır.

Saygının teorik bir bilgi gibi verilmesi etkili olmayacaktır. Türk (2009) yaptığı araştırma sonucunda öğretmenlerin sayg1 eğitimi uygulamalarında model olmayı vurguladıklarını belirtmiştir. Dilmaç (2002) da benzer şekilde saygı eğitiminde öncelikle öğretmenin model olması gerektiğini savunur. Bu öğretim süreci için önemli bir bulgudur ancak öğretimde ana kaynaklar her daim ders kitapları olmuştur. Bu bağlamda saygı değerinin öğretimi, içselleştirilmesi ve kullanımı için öğretmene yol gösterecek kaynak yine ders kitaplarıdır ve mutlaka değerlerin göstergeleri sayılabilecek ifade kalıplarının yazılı olarak bu kitaplarda yer alması ve saygı ifadelerinin bulunduğu etkinliklerin oluşturulması gerekmektedir.

Değerler eğitimi çalışmalarına sosyal bilimler alanlarında sıkça rastlanmaktadır. Değerler eğitiminde kaynaklar; basılı kaynaklar, sözlü kaynaklar, görsel kaynaklar ve dijital kaynaklar olarak ele alınabilir (Durmuş, 2011). Ancak Y11maz (2012), çocuğun evrensel değerlerin yanında mensubu olduğu milletin kültürel değerlerini mutlaka edinmesi ve bunun da Türkçe dersi kapsamında ele alınması ve edebi eserlerle verilmesinin uygun olacağını belirtmektedir. 
Değerlerin kazandırılmasıyla ilgili en uygun yaş dönemi olan soyut işlemler döneminin (10-11 yaş ve sonrası) başlangıcı olarak kabul edildiği için konuyla ilgili araştırmaların daha çok ilköğretim kademesinde yapıldığı anlaşılmaktadır. Bu çalışmada 5. sınıf Türkçe ders kitabının incelenme sebebi budur. Zira bu dönem "değer ve inanç sisteminin yapılandırıldığı" (Aktaran, Şen; 2008, Demircan 2006: 69) dönem olarak görülmektedir.

Değerler kavramına; bireysel, etik, toplumsal, dini, kültürel gibi pek çok başlıkta farklı bakış açıları da girmektedir. Bu çalışmada, daha ziyade toplumsal bakış açısıyla saygı değerinin eğitim alanında yer bulmasıyla ilgili araştırma yapılmıştır. Ayrıca araştırma sadece Türkçe dersi kapsamında söz konusu değerle ilgili ifade kalıplarının 5. sınıf Türkçe ders kitabındaki mevcudiyetini incelemektedir. Bu çalışmaya konu edilen değer, saygı kavramları ifadeleridir.

\section{Araştırmanın Amacı}

$\mathrm{Bu}$ araştırmanın amacı; Türkçe dersi kapsamında değerler eğitiminde karşılık bulan saygı ifade kalıplarının 5. sınıf Türkçe ders kitabında yer alma durumunu tespit etmek ve mevcut durumu ortaya koymaktır.

\section{Problem}

Değerler eğitimiyle ilgili saygı ifade kalıplarının 5. sınıf Türkçe ders kitabında yer alma düzeyi nedir?

- Metinlerde geçen saygı ifade kalıpları nelerdir? İfadelerin karşı1ıkları verilmekte midir?

- Etkinliklerde geçen saygı ifade kalıpları nelerdir? İfadelerin karşılıkları verilmekte midir?

- Doğrudan söz konusu kalıpların ele alındığ 1 bir tema, metin veya etkinlik var midır?

\section{Yöntem}

Bu bölümde araştırmanın deseni, yöntemi ve veri analizi hakkında bilgiler verilmiştir.

\section{Araştırmanın Deseni}

Çalışma, nitel araştırma olarak hazırlanmış ve nitel araştırma yöntemleri kapsamında, doküman taraması kullanılmıştır. Bu yöntem geçmişte ya da halen var 
olan bir durumu var olduğu şekliyle betimlemeyi amaçlayan araştırma yaklaşımına dayanmaktadır. Araştırma konusu olan olay, olgu, nesne, birey vb. kendi koşulları içinde ve olduğu gibi tanımlanmaya çalış1ır (Karasar, 2011: 77). Bu araştırmada 5. sınıf Türkçe ders kitabında değerler eğitimi kapsamında yer alan saygı ifade kalıplarının taranarak araştırmanın amacına hizmet eden verilerin belirlenmesi ve betimlenmesi tasarlanmıştır. Kullanılan araştırma aracı Özgün Yayınevi'nin hazırladığı 5. sınıf Türkçe ders kitabıdır. Kitap 2018 programına uygun olarak hazırlanmış en güncel kitaplardan biri olduğu için tercih edilmiştir. Bu bağlamda kitapta yer alan metinlerin tamamı ve metne bağlı etkinliklerin hepsi incelemeye dâhil edilmiştir.

\section{Veri Analizi}

Doküman taraması ile elde edilen verilerin analizinde, betimsel analiz yöntemi kullanılmıştır. Betimsel analizde amaç, doküman taramasıyla elde edilen bulguların yorumlanmış bir biçimde okuyucuya sunulmasıdır (Yıldırım ve Şimşek, 2008). Araştırmada 2018 yılında yayınlanan 5. sınıflar için Türkçe ders kitabı incelenerek saygı ifade kalıplarının bulunduğu metin ve etkinlikler belirlenmiştir. Belirlenen ifadeler tablolar hâlinde sunulmuş ve bulgular yorumlanarak mevcut durum ortaya koyulmuştur.

\section{Bulgular}

5. sınıf Türkçe ders kitabında, 8 tema, her temada da 6 metin bulunmaktadır. Bunlardan ilk üçü okuma metni, 4. dinleme / izleme metni, 5. serbest okuma metni, 6. ise tema sonu değerlendirmesidir. Çalışmada toplamda 48 metin ve bu metinlerin etkinlikleri incelenmiştir. Her metnin etkinlikleri olmasına karşın 5. serbest okuma metinlerinin etkinlikleri bulunmamaktadır. Aşağıda, temalar ve temalardaki metin ve etkinliklerde belirlenen saygı ifade kalıpları verilmektedir.

Tablo 1: Tema Metin Dă̆ı̆lımı

\begin{tabular}{ll}
\hline & Metin: Oyuncak (Okuma Metni) \\
& Metin: Çocukluk (Okuma Metni) \\
& Metin: Ben Bir Çınar Ağacıydım (Okuma Metni) \\
Metin: Anlamak (Dinleme / İzleme Metni) \\
Metin: Güneşin Uyuduğu Yer (Serbest Okuma Metni) \\
Tema Sonu Değerlendirmesi \\
\hline
\end{tabular}

Birinci temanın ilk 4 metninde ve tema sonu değerlendirmesinin metin ve etkinliklerinde saygı ifadesine rastlanmamıştır. Yalnızca 5. metin olarak yer alan “Güneşin Uyuduğu Yer” metninde (s.34 ) 2. paragrafta: 
Denize sordu: “Affedersiniz, öyle çok yoruldum ki... Biraz uyumazsam bitkinlikten mahvolacağım." cümlesinde "Affedersiniz" ifadesi bir saygı ifadesi olarak kabul edilebilir.

Masalda güneşin bu ifadesine deniz cevap vermemiştir. Ayrıca 4. paragrafta güneş, buluta: "Bir dakika bakar mısınız?” şeklinde saygıyla ve nazik bir soru sorduğunda, bulut: "Söyleyin ne istiyorsunuz?" şeklinde sert sayılabilecek bir üslupla cevap vermiştir.

Tablo 2: Tema Metin Dağılımı

\begin{tabular}{ll}
\hline & Metin: Bilmeyen Var mı? (Okuma Metni) \\
& Metin: Mustafa Kemal'in Kağnısı (Okuma Metni) \\
Millî Mücadele ve Atatürk & Metin: 15 Temmuz (Okuma Metni) \\
& Metin: Dersimiz Atatürk (Dinleme / İzleme Metni) \\
& Metin: Küçük Ağa (Serbest Okuma Metni) \\
& Tema Sonu Değerlendirmesi \\
\hline
\end{tabular}

İkinci temanın 1, 2, 3 ve 5. metinleri ve etkinlikleriyle tema sonu değerlendirmesi kısmında herhangi bir sayg1 ifadesi bulunmamaktadır. 4. metin olan "Dersimiz Atatürk" dinleme / izleme metninde az da olsa sayg1/nezaket ifadeleri yer almıştır. 1 saat 32 dakikalık filmin kitaptaki etkinliklerle alakalı olan kısımları 17 dakikalık bir kısmı barındırmaktadır. Okullarda genel olarak seyrettirilen bu kısımda aşağıdaki ifadeler kullanılmıştır:

- Günaydın çocuklar

- Sağ ol

- Teşekkür edelim

- Tebrik ederim

- Merhaba dede

- Hoş geldin

- Hoş buldum

Metnin 5. etkinliğinde (s.62) Amerikalı bir çocuğun Atatürk'e yazdığı ve Atatürk'ün de cevap verdiği iki mektuba yer verilmiştir. Amerikalı çocuk "Sayın büyüğüm" diye başladığı mektubu "Saygılarımla..." ifadesiyle bitirmiştir. Atatürk de "Bay Curtis Lafrance" şeklinde başlayan mektubunu "Başarılar ve mutluluklar dilerim." diyerek sonlandırmıştır. 2. temadaki saygı ifadeleri yalnızca bunlarla sınırlıdır.

Tablo 3: Tema Metin Dağılımı

Metin: Güvercin (Okuma Metni)

Metin: Hacivat İle Karagöz - İncelik (Okuma Metni)

Erdemler

Metin: Püf Noktası (Okuma Metni)

Metin: Adsız Çeşme (Dinleme / İzleme Metni)

Metin: Vakit Varken (Serbest Okuma Metni)

Tema Sonu Değerlendirmesi 
3. temanın ilk metni olan "Güvercin" metninde doğrudan bir saygı ifade kalıbına rastlanmamış sadece metnin son cümlesinde "Fare dostlarına da çok teşekkür ederek oradan ayrılmışlar." ifadesinin yer aldığı görülmüştür. Ancak bölümün son kısmında yer alan "Gelecek Derse Hazırlık" etkinliğinde öğrencilerden nezaket ve görgü kuralları konulu bir afiş hazırlanması istenmiştir.

3. temanın 2. metni olan "Karagöz ile Hacivat - İncelik" metninde saygı ve nezaket ifade kalıpları bulunmaktadır. Hazırlık çalışmalarında aşağıdaki soru yer almış ve bu ifadelerin konuşma ya da yazma etkinliğiyle aktarılması istenmiştir.

\section{HAZIRLIK ÇALIŞMALARI}

1. "Elinize sağlık, affedersiniz, kusura bakmayın..." ifadeleri aşağıdakilerden hangisiyle ilgilidir? İşaretlediğiniz kuralların günlük hayatınızdaki yeri ve önemini açıklayınız.

$$
\text { Temizlik kuralları__ Görgü kuralları ve nezaket }
$$

Metinde Hacivat Karagöz geleneğine uygun olarak Hacivat, bilgili ve kibar; Karagöz ise kaba ve sert konuşturulmuştur. Bu sebeple Hacivat'ın nezaket ifadelerine Karagöz aynı şekilde karşılık vermemiştir. Metinde Hacivat:

- Günaydin

- Hoş geldiniz, safa geldiniz, keyifler nasıl?

- Efendim

- Güle güle kullan, başında paralansın

- Güle güle yak, otur da külüne bak

- Güle güle oturunuz, içinden hiç çıkmayınız

ifadelerini kullanmış, ancak Karagöz'den -oyunun doğası gereği- aynı karşılığ 1 görememiştir.

Metnin 1, 3 ve 4. etkinliklerinde sayg//nezaket kalıplarına çocukların dikkatini çekecek içeriklere yer verilmiştir.

1. ETKIN LiKK Aşağıdaki cümlelerde altı çizili deyimlerin anlamlarını yazınız.

* Efendim, başıma bir şapka almak için çarşıya gitmiştim. Dönerken yorgunluk çıkarmak üzere

Karagöz'e uğrayayım, dedim.

* Eksik olma Karagöz'üm!

Metnin 3 ve 4. etkinlikleri saygı ve nezaket ifade kalıplarını barındırma açısindan verimli niteliktedir. 
3.ETKINLIK $\quad$ a) Günlük hayatta karşılaştığımız bazı durumlar aşağıda sıralanmıştır. Bu durumlar karşısında kullandığımız nezaket ifadelerini örnekteki gibi yazınız.

\begin{tabular}{|l|l|}
\hline \multicolumn{1}{|c|}{ DURUMLAR } & NEZAKET iFADELERI \\
\hline Akşam yatmaya giderken & iyi geceler. \\
\hline Bir kişi yolculuğa çıkarken & \\
\hline Herhangi bir hata yaptığımızda & \\
\hline Birisi yeni bir kıyafet aldığında & \\
\hline Bir yerden ayrılırken & \\
\hline Bir işle meşgul birine & \\
\hline Birisi seslendiğinde & \\
\hline Bir ortama girdiğimizde & \\
\hline Herhangi bir şey yedikten sonra & \\
\hline Bizim için bir iyilik yapıldığında & \\
\hline
\end{tabular}

Özellikle 3. etkinlikteki "karşılık bulma" çalışması dikkat çekmektedir. 4. etkinlikte ise metinde geçen durumlar verilmiş ve eşleştirme yapılması istenmiştir.

4.ETKINLiK Metinde geçen durumlar aşağıda karışık olarak verilmiştir. Siz de bu durumları örnekteki gibi eşleștiriniz.

HACIVAT

Pide almaya gittiğimde kaza ile firıncının küreğinin sapı gözüme gelmez mi?

Kavga edenleri ayırmak için aralarına girdim. $O$ sırada gelen polisler beni de karakola götūrdüler. Oradan da doğru hapishaneye...

Evde odun bitmiș. Beş on çeki odun aldım. Beş on çuval da kömür aldım.

Evin kiremitleri kırılmış, yağmur evin içine akryor. Bir usta çağırdım. Evi bir gūzel onardı.

Bugün çarşıdan bir şapka aldım.
ÖYLE DENMEZ KARAGÖZ!

\section{NASIL DENIR?}

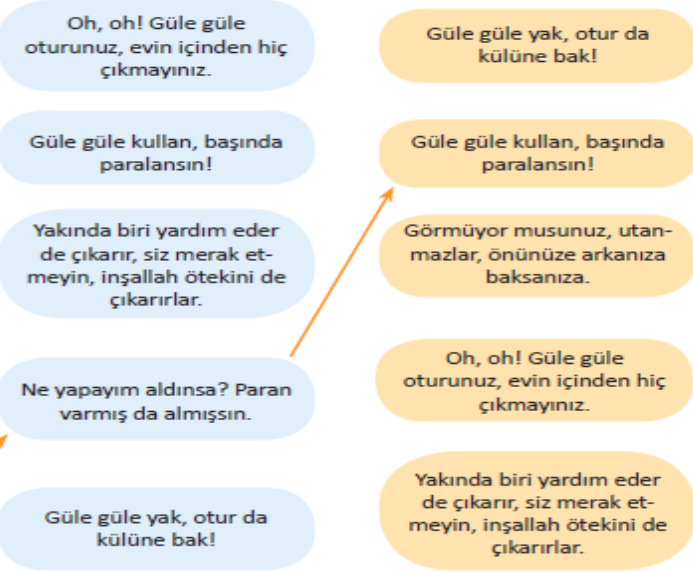

Temanın diğer parçalarında ise herhangi bir ifade kalıbı yer almamaktadır.

Tablo 4: Tema Metin Dağılımı

Metin: Uzayda Bir Gün (Okuma Metni)

Metin: Sarımsak Soslu Makarna (Okuma Metni)

Bilim ve Teknoloji

Metin: Bir Dâhiyle Konuşmak (Okuma Metni)

Metin: Sanki Caminin Bakım Kılavuzu (Dinleme / İzleme Metni)

Metin: Jules Verne'den Geleceğe Dair (Serbest Okuma Metni)

Tema Sonu Değerlendirmesi 
4. temadaki metin ve etkinlerde saygı ifadesine rastlanmamıştır. Yalnızca temanın ilk metni "Uzayda Bir Gün” metninin 7. etkinliğinde dilekçe örneği verilmiş ve dilekçenin sonunda "Gereğini arz ederim." ifadesi yer almıştır (s.111).

Temanın ikinci metni olan "Sarımsak Soslu Makarna” adlı metinde duyular ve duyu organları işlenirken kısmen de olsa tariften bahsedilmiş ancak "Elinize sağlık" veya "Afiyet olsun." ifadeleri bile yer almamıştır.

Tablo 5: Tema Metin Dağılımı

Metin: Anadolu Sevgisi (Okuma Metni)

Metin: Forsa (Okuma Metni)

Millî Kültürümüz

Metin: Tamburi Cemil Bey Enstrümanları Anlatıyor (Okuma Metni)

Metin: Dede Korkut - Boğaç Han (Dinleme / İzleme Metni)

Metin: Çocuk Doğru Söyledi (Serbest Okuma Metni)

Tema Sonu Değerlendirmesi

5. tema okuma metinlerinin hiçbirinde saygı ifade kalıpları kullanılmamıştır. Sadece dinleme / izleme metni olan Dede Korkut - Boğaç Han hikâyesinde bir tane “- Ziyafetiniz hoş olsun." ifadesi yer almıştır.

Tablo 6: Tema Metin Dağılımı

Metin: Okuma Kitaplarım (Okuma Metni)

Metin: Kitabın Serüveni (Okuma Metni)

Metin: Karikatür (Okuma Metni)

Okuma Kültürü

Metin: Küçük Şeylerin Hikâyesi - Kütüphane (Dinleme / İzleme

Metni)

Metin: Keramet Tavukta mı? (Serbest Okuma Metni)

Tema Sonu Değerlendirmesi

6. temanın metin ve etkinliklerinde saygı ifade kalıpları kullanılmamıştır.

Tablo 7: Tema Metin Dağılımı

Metin: Anadolu'nun Cirit Oyunları (Okuma Metni)

Metin: Sağlıklı Yaşıyorum (Okuma Metni)

Sağlık ve Spor

Metin: Cazgır (Okuma Metni)

Metin: Bilinçsiz İlaç Kullanımı (Dinleme / İzleme Metni)

Metin: Hasta (Serbest Okuma Metni)

Tema Sonu Değerlendirmesi

7. temanın metinleri incelendiğinde ilk üç metin ve metinlerin etkinliklerinde herhangi bir saygı ifadesi kalıbının yer almadığı görülmektedir. Sadece 4. metin olan "Bilinçsiz İlaç Kullanımı" dinleme / izleme metninde, aşağıdaki ifadelerin kullanıldığg görülmektedir:

-Peki, hanımefendi. Iyi günler, geçmiş olsun.

-Geçmiş olsun Makbule teyze

-Efendim dedeciğim. 
7. temanın "Hasta" başlıklı serbest okuma metninde ise aşağıdaki ifadeler kullanılmıştır:

-Canım, senin canın să̆ olsun.

-Vah vah, geçmiş olsun. Büyük kaza geçirmişsin (s.216-217).

Tema sonu değerlendirme kısmında saygı ifadeleri yer almamaktadır.

\begin{tabular}{ll}
\hline Tablo 8: Tema Metin Dağılımı \\
\hline \\
Metin: Yüksek Evde Oturanın Türküsü (Okuma Metni) \\
Metin: Reçete (Okuma Metni) \\
Metin: Kar Tanesinin Serüveni (Okuma Metni) \\
Metin: Kuş Ağacı (Dinleme / İzleme Metni) \\
Metin: Eyvah, Ormanda Kayboldum! (Serbest Okuma Metni) \\
Tema Sonu Değerlendirmesi \\
\hline
\end{tabular}

Temanın birinci metninde herhangi bir saygı ifadesi yer almazken metnin 8 . etkinliğinde nezaket ifadesi sayılabilecek sadece bir ifade kalıbı göze çarpmaktadır: "E-postanı bekliyorum, görüşmek üzere arkadaşım."

Temanın 2. metninde saygı ifadesine yer verilmemiştir. Ancak metnin 4. etkinliğinde Barış Manço'nun "Nane Limon Kabuğu” şarkısının öğrencilere dinletilmesi istenmiştir ve söz konusu parçada: "Çok yaşa, Sen de gör, Rahat ve iyi yaşa " kalıp ifadeleri geçmektedir.

\section{Sonuç}

Değerler eğitimiyle ilgili saygı ifade kalıplarının 5. sınıf Türkçe ders kitabında yer alma durumu kitapta bulunan 8 temanın her birinde 6 metin yani toplam 48 metin ve bu metinlerle bağlantılı etkinlikler incelenerek belirlenmiştir. Temalara göre metinlerde ve etkinliklerde geçen saygı ifade kalıplarının kullanım durumu şöyledir:

1. temada sadece bir metinde, 2 . temada bir metin ve bir etkinlikte, 3 . temada iki metin ve dört etkinlikte, 4. temada bir etkinlikte, 5. temada bir etkinlikte, 7 . temada iki metinde ve 8 . temada 2 etkinlikte sayg ifade kalıplarının kullanıldığ 1 görülmüştür. 6. temada ise hiçbir sayg1 ifadesi içeren cümle bulunamamıştır. Kullanılan ifadelere cevap olarak karşılık örnekleri ise sadece 3. temadaki Karagöz ve Hacivat metninde içeriğin doğal özelliği itibariyle yer almıştır.

Bunun dışında doğrudan saygı ve nezaket ifade kalıplarının kullanımına dair yine sadece 3. temadaki Karagöz ve Hacivat metninden sonraki etkinliklerde yer verilmiştir. 
Bu sonuçlardan yola çıkarak programlarda değerler eğitimi sıkça ve özellikle vurgulansa da konunun daha çok öğretmen uygulamaları üzerinden götürüldüğü söylenebilir. Zira Türk (2009) de ilköğretim ve ortaöğretim öğretmenlerinin bu çalışmaya da konu olan saygı değeriyle ilgili alg1, tutum ve eğitimsel uygulama durumlarını inceleyen bir araştırma yapmış ve araştırma bulgularına göre öğretmenlerin; nezaketin ve karşılıklı saygının yer aldığı bir sınıf ortamı oluşturmaya çabaladıkları, başkalarının sözünü kesmeden dikkatle dinleyerek karşısındakine nasıl saygı göstereceğini öğretmeye çalıştıkları ve başkalarına sayg1 göstermede davranış modeli oluşturmaya önem vererek saygı değerinin öğretmeye çalıştıklarını belirlemiştir. Bu bulgular, ders kitabında yeterince yer almadığında konunun öğretmen yaklaşımı ve inisiyatifine kaldığını kanıtlar niteliktedir. Ateş (2013) ise öğretmenlerin değerler eğitimine ilişkin görüşlerini aldığ çalışmasında öğretmenlerin okullarda değerler eğitimi uygulamalarının sadece kâğıt üzerinde kaldığını hâlbuki değerler eğitiminin okullarda sosyal faaliyetler ya da etkinlikler olarak planlanıp daha fazla yer almasının gerektiğini belirtmektedir. Baysal (2013) değerler eğitimi uygulamalarında öğretmenlerin en çok örnek olay yöntemini kullandıkları, en az ise teşekkür mektubu yazdırma tekniğini kullandıklarını tespit etmiştir.

Öğretici (2011) de bu çalışmanın sonucunu destekler nitelikte, bir çalışmasında değerler eğitimi etkinliklerinin etkililiğini belirlemeye yönelik bir araştırma gerçekleştirmiş ve araştırma sonunda ise uygulanan sınıf içi etkinliklerin değerlere ilişkin farkındalığı arttırdığını ancak mevcut değerler eğitimi uygulamalarının yetersiz olduğunu, ders kitapları ile programın yapısının değerler eğitimi için çok da uygun olmadığını belirlemiştir.

Özellikle iletişimin temel aracı olan dil öğretimi ve Türkçe dersleri kapsamında değerlerin öğretilmesi ve içselleştirilerek kullanım uygulamalarının sıkça gerçekleştirilmesi gerekmektedir. Bu bağlamda öncelikle öğretmene örnek ve kaynaklık edecek ders kitaplarındaki metin ve etkinliklerin değerlerimizi yans1tan kalıp ifade yollarını barındırmaya özen göstermesi faydalı olacaktır.

\section{Kaynakça}

Akgül, İ. (2014). Illkokul öğrencileri için web tabanlı değerler eğitimi (Yayımlanmamış yüksek lisans tezi). Uşak Üniversitesi, Sosyal Bilimler Enstitüsü, Uşak.

Akkaya, S. (2013). Mevlâna'nın mensur eserlerinde değerler eğitimi (Yayımlanmamış yüksek lisans tezi). İnönü Üniversitesi Eğitim Bilimleri Enstitüsü, Malatya. 
Aktürk, F. G. (2012). Çocukta değerler eğitimi açısından Üzeyir Gündüz'ün eserleri (Yayımlanmamış yüksek lisans tezi). Afyon Kocatepe Üniversitesi, Sosyal Bilimler Enstitüsü, Afyonkarahisar.

Aslan, M. (2009). Değerler eğitiminde kahramanlardan yararlanma (Yayımlanmamış yüksek lisans tezi). Gazi Osman Paşa Üniversitesi Sosyal Bilimler Enstitüsü, Tokat.

Ateş, F. (2013). İlkokul ve ortaokul ögretmenlerinin değerler eğitimi ve uygulamalarına yönelik görüşleri üzerine nitel bir araştırma, (Yayımlanmamış yüksek lisans tezi). Yeditepe Üniversitesi, Sosyal Bilimler Enstitüsü, İstanbul.

Atmaca, G. (2011). Çocuklara Mahsus Gazete'de değerler eğitimi (1-100 sayllar) (Yayımlanmamış yüksek lisans tezi). Marmara Üniversitesi Sosyal Bilimler Enstitüsü, İstanbul.

Aydın, M. Z. (2006). İnsanın Değerler Eğitimi, Eğitim Yazıları, 10, 65-81.

Bağcı, E. (2013). Çocuk edebiyatı ürünleriyle çocuklar için yazılmış eserlerin değerler eğitimi bağlamında karşılaştırılması (Yayımlanmamış yüksek lisans tezi). Celal Bayar Üniversitesi, Sosyal Bilimleri Enstitüsü, Manisa.

Baysal, N. (2013). Ortaokul sosyal bilgiler derslerinde değerler eğitimi uygulamalarının ögretmenler yönüyle değerlendirilmesi (Yayımlanmamış yüksek lisans tezi)., Niğde Üniversitesi, Eğitim Bilimleri Enstitüsü, Niğde.

Biçer, S. (2013). Değerler eğitimi açısından Mehmet Akif Ersoy'a ait Safahat adlı eserin incelenmesi (Yayımlanmamış yüksek lisans tezi). Uşak Üniversitesi, Sosyal Bilimler Enstitüsü, Uşak.

Can, Ö. (2008). Dördüncü ve beşinci sinlf ögrretmenlerinin sosyal bilgiler dersinde değerler eğitimi uygulamalarına ilişkin görüleri (Yayımlanmamış yüksek lisans tezi). Hacettepe Üniversitesi, Sosyal Bilimler Enstitüsü, Ankara.

Coşkun, D. (2011). İlköğretim birinci kademe 5. sinıf sosyal bilgiler dersinde değerler eğitimi (Denizli ili örneği) (Yayımlanmamış yüksek lisans tezi). Pamukkale Üniversitesi, Sosyal Bilimleri Enstitüsü, Denizli.

Çengelci, T. (2010). İlköğretim beşinci sinıf sosyal bilgiler dersinde değerler eğitiminin gerçekleştirilmesine iliş̧kin bir durum çalışması (Yayımlanmamış yüksek lisans tezi). Anadolu Üniversitesi, Eğitim Bilimleri Enstitüsü, Eskişehir.

Demircan, C. (2006). Mektepli Gazetesi'nde yer alan metinlerin içeriğinin çocukların bilişsel ve ahlaki gelişmelerine katkısı (1-148. Sayılar) (Yayımlanmamış yüksek lisans tezi).Mersin Üniversitesi, Sosyal Bilimler Enstitüsü, Mersin.

Demirtaş, T. (2012). Değerler eğitiminde edebî ürünlerden yararlanma: Nasreddin Hoca fikraları (Yayımlanmamış yüksek lisans tezi). Sakarya Üniversitesi, Eğitim Bilimleri Enstitüsü, Sakarya.

Deniz, K. ve Karagöl, E. (2018). Değerler eğitimi açısından ortaokul Türkçe ders kitapları, Karaelmas Eğitim Bilimleri Dergisi, 6 (2), 244-255. 
Dilmaç, B. (2002). Insanca değerler eğitimi, (1. Baskı). Nobel Yayın Dağıtım, Ankara.

Durmuş, S. (2011). İlköğretim matematik öğretmen adaylarının sahip olduğu değerler ve modelleme düzeylerine ilişkin bir inceleme. Kuram ve Uygulamada Eğitim Bilimleri (KUYEB), 11(2), 1055-1071.

Engin, G. (2014). Türkçe ve beden eğitimi öğretim programlart ile bütünleştirilmiş değerler eğitimi programının etkililiği (Yayımlanmamış yüksek lisans tezi). Çanakkale On Sekiz Mart Üniversitesi, Eğitim Bilimleri Enstitüsü, Çanakkale.

Ercan, A. N. (2014). Etfal Gazetesi 'nin metin ve değerler eğitimi açısından incelenmesi (Yayımlanmamış yüksek lisans tezi). Necmettin Erbakan Üniversitesi, Eğitim Bilimleri Enstitüsü, Konya.

Güçlü, M. (2015). Türkiye'de değerler eğitimi konusunda yapılan araştırmalar, Uluslararası Sosyal Araştırmalar Dergisi, 8(38), 720-732.

Gül, M. (2017). Türkçe ders kitabındaki metinlerin (5. sınıf) değerler eğitimi yaklaşımıyla incelenmesi. Erciyes Journal of Education, 1(1), 59-78.

Izgar, G. (2013). Illköğretim okulu 8. sinıf ögrencilerine uygulanan değerler ĕ̆itimi programının demokratik tutum ve davranışlarına etkisi (Yayımlanmamış doktora tezi). Necmettin Erbakan Üniversitesi, Eğitim Bilimleri Enstitüsü, Konya.

İşcan, C. D. (2007). Illköğretim düzeyinde değerler eğitimi programının etkililiği (Yayımlanmamış doktora tezi). Hacettepe Üniversitesi, Sosyal Bilimler Enstitüsü, Ankara.

Kantar, Ş. (2014). Ilköğretim 4 ve 5. sinıf sosyal bilgiler dersinde 100 temel eser yoluyla değerler eğitimi (Yayımlanmamış yüksek lisans tezi). Necmettin Erbakan Üniversitesi Eğitim Bilimleri Enstitüsü, Konya.

Karasar, N. (2011). Bilimsel araştırma yöntemi (22. Basım), Ankara: Nobel Yayınevi.

Kasapoğlu, H. (2013). Okulda değer eğitimi ve hikâyeler. Milli Ĕ̆itim Dergisi, s. 198, 97- 104.

Kaynak, L. (2012). Değerler eğitimi bağlamında Sevinç Çokum'un hikâyelerinin analizi (Yayımlanmamış yüksek lisans tezi). Akdeniz Üniversitesi, Sosyal Bilimler Enstitüsü, Antalya.

Keskinoğlu, M. Ş. (2008). Illköğretim beşinci sınıf öğrencilerine uygulanan mesnevi temelli değerler eğitimi programının ahlaki olgunluğa ve saldırganlık eğilimine etkisi (Yayımlanmamış yüksek lisans tezi). Yeditepe Üniversitesi, Sosyal Bilimler Enstitüsü, İstanbul.

Kova, Ö. (2014). TRT Repertuvarında bulunan değiş ve semahların müzikal analizi ve değerler eğitimi açısından incelenmesi (Yayımlanmamış yüksek lisans tezi). Fırat Üniversitesi, Sosyal Bilimler Enstitüsü, Elazığ. 
Kumbasar, E. (2011). Muzaffer İzgü'nün romanlarının değerler eğitimi açısından incelenmesi (Yayımlanmamış yüksek lisans tezi). Karadeniz Teknik Üniversitesi, Eğitim Bilimleri Enstitüsü, Trabzon.

Latifoğlu, N. (2013). Çocuklara Mahsus Gazete'de değerler eğitimi (101-200. sayılar) (Yayımlanmamış yüksek lisans tezi). Marmara Üniversitesi, Eğitim Bilimleri Enstitüsü, İstanbul.

MEB, (2019). Türkçe Dersi Öğretim Programı (İlkokul ve Ortaokul 1, 2, 3, 4, 5, 6, 7 ve 8 . Siniflar), Ankara.

Öğretici, B. (2011). İlköğretim 6. slnıf sosyal bilgiler derslerinde değerler eğitimine yönelik uygulamaların etkililiğinin araştırılması (Yayımlanmamış yüksek lisans tezi). Sakarya Üniversitesi, Eğitim Bilimleri Enstitüsü, Sakarya.

Özdaş, F. (2013). Ortaokullarda değerler eğitimi ve istenmeyen öğrenci davranışlarına ilişkin öğretmen görülerinin değerlendirilmesi (Yayımlanmamış yüksek lisans tezi). Fırat Üniversitesi, Sosyal Bilimler Enstitüsü, Elazığ.

Padem, S. ve Aktan, O. (2014). İlköğretim 5. sınıf Türkçe ders kitabında yer alan değerlerin incelenmesi. Düzce Üniversitesi Sosyal Bilimler Enstitüsü Dergisi, 4 (2), 5-24.

Pilav, S. ve Erdoğan Ş. (2016). Ortaokul Türkçe ders kitaplarındaki bilgilendirici metinlerin değer iletimi açısından incelenmesi. Millî Eğitim Dergisi, 210, 351-371.

Sallabaş, M. E. (2012). Ömer Seyfettin Hikâyelerinin Türkçe öğretiminde değer aktarımı bakımından incelenmesi, Mustafa Kemal Üniversitesi Sosyal Bilimler Enstitüsü Dergisi, 3 (2), 59-68.

Selek, M. (2014). Osman Yalçın'ın hayvan hikâyelerinde değerler eğitimi (Yayımlanmamış yüksek lisans tezi). Mehmet Akif Ersoy Üniversitesi, Eğitim Bilimleri Enstitüsü, Burdur.

Şen, Ü. (2008). Altıncı sınıf Türkçe ders kitaplarındaki metinlerin ilettiği değerler açısindan incelenmesi, Uluslararası Sosyal Araştırmalar Dergisi, 1(5), 763-779.

Tokdemir, M. A. (2007). Tarih öğretmenlerinin değerler ve değer eğitimi hakkındaki görü̈sleri (Yayımlanmamış yüksek lisans tezi). Karadeniz Teknik Üniversitesi, Sosyal Bilimler Enstitüsü, Trabzon.

Türk, İ. (2009). Değerler eğitiminde saygı (Yayımlanmamış yüksek lisans tezi). Gazi Osman Paşa Üniversitesi, Sosyal Bilimler Enstitüsü, Tokat.

Uzunkol, E. (2014). Hayat bilgisi ögretiminde uygulanan değerler eğitimi programının ögrencilerin özsayg düzeyleri, sosyal problem çözme becerileri ve empati düzeylerine etkisi (Yayımlanmamış doktora tezi). Gazi Üniversitesi, Eğitim Bilimleri Enstitüsü, Ankara. 
Yazar, T. (2010). İlköğretim sosyal bilgiler programında değerler eğitiminin mevcut durumunun belirlenmesi ve ögretmenlere yönelik bir program modülü geliştirme (Yayımlanmamış yüksek lisans tezi). Mersin Üniversitesi, Sosyal Bilimler Enstitüsü, Mersin.

Yıldırım, A. ve Şimşek, H. (2008). Nitel araştırma yöntemleri. (6.Baskı). Ankara: Seçkin Yayıncılık.

Yılmaz, E. (2012). Ziya Gökalp'in şiirlerinin değerler eğitimi açısından incelenmesi (Yayımlanmamış yüksek lisans tezi). Karadeniz Teknik Üniversitesi Eğitim Bilimleri Enstitüsü, Trabzon.

Yiğittir, S. ve Öcal, A. (2011). Lise tarih öğretmenlerinin değerler ve değerler eğitimi konusundaki görüşleri, KMÜ. Sosyal ve Ekonomik Araştırmalar Dergisi, $13(20), 117-124$. 
Extended Abstract

\section{The Patterns of Expression of Respect Value in 5th Grade Turkish Textbook}

Filiz METE, Corresponding Author, Assoc. Prof.

Hacettepe University, Faculty of Education.

E-mail: flzmt27@gmail.com

ORGID: 0000-0002-8835-3884

Murat DAĞ, Phd. Student, Teacher.

E-mail: dag390@gmail.com

ORCID: 0000-0001-6152-2425

\section{Introduction}

The virtue of being able to distinguish the right from wrong directly, and to behave with respect is what distinguishes man from the animal. The ideal person lives in accordance with the values, moral norms and rules of the society in which he is located. The cultural fabric that holds society together is the loop of common values. Values, roots and traditions in our past, the body and branches of these roots that we nourish today will extend to tomorrow. The task of teaching values is primarily the responsibility of the families and then the teachers.

Children who receive values education from their parents in a completely natural way until they start school, where they are taught values in a planned and conscious way. Because values indirectly have the power to change the life and development of societies. It is important to transfer social values and moral standards to future generations. Therefore, the subject of values education took its place in the curriculum prepared in 2005 . Especially since then the researches 
started to be conducted on the reflections and effectiveness of values education. In our curriculum, our values are not included as a separate program or learning area, but as the ultimate goal and spirit of the whole educational process and are reflected in each unit of the curriculum. The root values of the 2019 Turkish curriculum are: justice, friendship, honesty, self-control, patience, respect, love, responsibility, patriotism, helpfulness. When the values are examined, it will be understood that respect is actually the basis of almost all values. In the absence of respect; talking about love, justice, peace, tolerance or benevolence is futile. With this in mind, the study is limited to respect value only.

In the literature, studies on values education are generally considered in connection with the fields of social studies, life science or history, or have been carried out through examination of materials used in teaching. Many researchers in the aforementioned fields have examined materials such as textbooks, literary works, stories, texts, newspapers, magazines in terms of content, usage, and values education. Also, researches on approaches and methods used in values education are also available. However, studies on values education directly related to Turkish or related to Turkish textbooks were found to be insufficient. The common feature of these studies is the determination of the values in books and sources and the frequency of use. When the results are examined, it is found that love value is the most commonly used concept in almost every study. Şen (2008) examined the values conveyed by the texts in the 5 Turkish textbooks prepared for the sixth grade, listed the distribution of the values in the texts, and found that the most commonly used value was love in all 5 books, but that the texts were insufficient in transferring the determined values.

The most important tool in communication is language. One concrete indicator of respect is the use of expressions of respect when communicating. Turkish courses are designed to improve language skills and the correct and effective use of verbal or written expressions is covered in these courses. Baysal (2013), as a result of the research that the teacher opinions about values education practices; it is determined that teachers mostly use case study method in values education practices and at least use method was thank-you letter writing. But thank you, perhaps, is the most common pattern used in all languages and is so important that it is accepted as the password of civilization. It is the most important indicator of the respect we show to the individual we are dealing with. Responding to a 'thank you' is as important as thanking. For example, in response to a 'thank you', expressive patterns like; thank you, don't mention 
it, no problem, no worries, are used. In this context, opportunities should be created for teaching the patterns to be used for thanking which is the beginning of teaching respect and students should be provided with opportunities to use these expressions.

As in all languages, in Turkish, in the first place, there are some words gestures and expressions that express the feelings of 'thank you' and 'please'. In values education, it is aimed to know, internalize and use the relevant point, when necessary. Although specially developed scales are used in the studies of measuring the effect of values education, there are studies showing that teachers make decisions based on behavioral observations about students. Of course, the ultimate goal is behavioral outcomes, not cognitive or affective. In other words, the individual, who knows and internalizes, is expected to be able to use what they know and internalize by reflecting them on their behavior. However, there are concerns about the reliability of the unstructured scientific observations. In this context, it would be appropriate to support, investigate and to increase the scientificity of the discourse used in obtaining the teachers' views in which statement like of "I have observed after the values education, and I found it sufficient".

Giving respect as theoretical knowledge will not be effective. Türk (2009) stated that teachers emphasized to be a model in respect education practices. Dilmaç (2002) likewise argues that the teacher should be a model in the education of respect value. This is an important finding for the teaching process, but the main sources of teaching have always been textbooks. In this context, the source that will guide the teacher for the teaching, internalization and use of respect value is again textbooks and it is absolutely necessary to include the expression patterns that can be considered as indicators of values in these books and to create activities with respect expressions. Values education studies are frequently seen in social sciences. Resources in values education; printed sources, oral sources, visual sources and digital sources (Durmuş, 2011). However, Y1lmaz (2012) states that it is appropriate for the child to acquire the cultural values of the nation of which he is a member as well as universal values, and that this should be handled within the scope of the Turkish courses and conveyed through literary works.

Since it is accepted as the beginning of the abstract process period (10-11 years and beyond), which is the most appropriate age period for the acquisition of values, we can see that most researches on the subject are mostly conducted 
in primary education level. This is the reason why 5 th grade Turkish textbook is examined in this study. Because this period is seen as the period in which the value and belief system was structured (Demircan 2006: 69). The concept of values; individual, ethics, social, religious, cultural, and so on. In this study, research has been made about the place of respect in the field of education from a social point of view. In addition, the research only examines the existence of the expression patterns related to the value in the Turkish course in the 5th grade Turkish textbook. The subject of this study are expressions of value and respect.

The aim of this research is to determine the status of the expressions of respect in the 5th grade Turkish textbook. The problem is to determine whether or not the level of the value of respect education is sufficient in the 5th grade Turkish textbook. In this context, the expressions of respect in the texts and activities and whether there are reciprocal expressions or there is a theme, text or activity with direct expressions of respect are investigated.

\section{Method}

The study was designed as qualitative research and document analysis was used within the scope of qualitative research methods. In this study, it was designed to identify and describe the data that serve the purpose of the research by scanning the respect expression patterns in the 5 th grade Turkish textbook within the scope of values education. The research tool used is the 5 th grade Turkish textbook prepared by Özgün Yayınevi. The book was chosen as it is one of the most current books prepared in accordance with the 2018 program. In this context, all the texts in the book and all the activities related to the text were included in the analysis. Descriptive analysis method was used in the analysis of the obtained data. The statements were presented in tables and the findings were interpreted and the current situation was revealed.

\section{Result}

As a result, it was determined that the textbook contains value, but expressions of the value of respect in texts or activities were found to be insufficient. The status of the value of respect expression patterns related to values education in the 5 th grade Turkish textbook was determined by examining 6 texts, i.e. a total of 48 texts in each of the 8 themes, and the activities related to these texts. 
No expression of respect was found in the first 4 texts of the first theme and in the texts and activities of the end-of-theme evaluation. Only in the 5th text the statement "excuse me"can be regarded as an expression of respect. Texts 1 , 2, 3 and 5 of the second theme and activities and end-of-theme evaluation do not show any expression of respect. In the text of the 4th, there is little respect / courtesy expressions. For example; good morning, thank you, congratulations, welcome, dear, sorry, I wish you a good day, best regards. In the first text of the third theme, there was no direct pattern of respect, but in the last sentence of the text, it was observed that the expression of thanks was very much appreciated. However, students were asked to prepare a poster about courtesy and etiquette. In the second text of theme 3, there are expressions of respect and courtesy like; good Morning, welcome, sorry, good-bye. In the text and activities of theme 4, respect was not found. Expression of respect were not used in any of the reading texts in theme 5 , same as the theme 6 . When the texts of the 7 th theme are examined, it is seen that the first three texts and their activities do not have any expressions of respect.

Especially in the context of language teaching and Turkish lessons, which are the basic means of communication, values usage should be taught and internalized, and practices should be realized frequently. In this context, first of all, it will be useful to make sure that the texts and activities in the textbooks, which will serve as examples and resources for the teacher, are prepared with care to accommodate traditional expressions that reflect our values. 